\title{
PENGUATAN MANAJEMEN DAN KEPEMIMPINAN PESANTREN DALAM MEWUJUDKAN LEMBAGA PENDIDIKAN ALTERNATIF IDEAL
}

\author{
Abdul Muis \\ Institut Agama Islam Negeri Jember \\ abdulmuis1871@gmail.com
}

DOI: https://doi.org/10.35719/jieman.v2i2.32

\begin{abstract}
Abstrak
Pesantren sebagai sebuah kultur ataupun sub kultur dalam penjalanannya mengalami perkembangan yang cukup signifikan, baik dalam sistem pengajaran maupun manjememen kelembagaan. Pada sistem pengajaran, pesantren mengalami perubahan selain karena menerapkan model salaf seperti sorogan dan wetonan tetapi juga karena mengadopsi model madrasi. Dengan menggunakan metodologi kepustakaan, tujuan penulisan artikel ini adalah untuk mengetahui penguatan manajemen pesantren dalam mewujudkan lembaga pendidikan alternatif ideal. Hasil dari penelitian ini menujukan bahwa pesantren menerapkan pengelo-laannya dengan pendekatan manajemen modern, karena pada awal-awal berdirinya pesantren, hampir seluruh pesantren di Indonesia menerapkan pola kepemimpinan karismatik yang terpusat pada sosok pengasuh (kiai), namun saat ini model kepemimpinan yang diterapkan mengalami perubahan karena pesantren menerapkan model kepemimpinan kolektif. Oleh kerena itu, banyak yayasan di dalam pesantren yang menerapkan kepemimpinan kolektif.
\end{abstract}

Kata Kunci: manajemen pesantren, kepemimpinan pesantren, lembaga pendidikan alternative

\section{Abstract}

Pesantren as a culture or sub-culture, within its enactment, has developed quite significantly, both in the teaching system and institutional 
management. In the teaching system, pesantren have undergone changes not only for applying the salaf based learning model such as sorogan and wetonan but also for adopting the madrasi's model. As it used Literature review based methodology, this study aims to strengthen the pesantren's management in realizing an ideal alternative educational institutions. The results of this study indicate that pesantren or Islamic boarding schools utilizes modern based management approach, because in the early development of pesantren, it implemented a charismatic leadership pattern centered on the role-modeling figure of a caregiver (kiai). However, the leadership model itself has changed into a collective leadership model. Due to this reason, some educational foundations of pesantren apply such collective leadership.

Keywords: pesantren's management, pesantren's leadership, alternative educational institutions

\section{Pendahuluan}

Peran pesantren saat ini menunjukkan perkembangkan yang signifikan. Hal ini bisa dilihat dari terus berkembangnya pesantren baik secara kuantitas maupun kualitas. Di samping itu, bermunculan wacana, kajian, dan penelitian para ahli yang berkaitan dengan pesantren. Bahkan, pada tahun 2019 pemerintah bersama DPR menetapkan Undang-Undang Nomor 18 Tahun 2019 tentang Pesantren.

Realitas ini tidak terlepas dari kontribusi dan peran pesantren dalam membangun peradapan sosial masyarakat. Pasalnya, pesantren bukan saja sebagai "sub kultur" namun juga merupakan "institusi kultural” karena pesantren memiliki karakter budaya tersendiri yang merupakan ciri khasnya serta tidak menutup diri terhadap pengaruh budaya luar. ${ }^{2}$ Pesantren memiliki prinsip memelihara sesuatu yang sudah baik, namun mengambil sesuatu yang dianggap lebih baik. Dengan bermodal kekhasan karekter inilah pesantren sebagai lembaga pendidikan mampu melewati tantangan zaman, mulai dari zaman penjajahan, kemerdekaan, masa Orde Lama, Orde Baru bahkan sampai pada masa reformasi. Bahkan, dalam setiap masa, pesantren berperan aktif serta berkontribusi untuk kebaikan bangsa ini, dan melalui

${ }^{1}$ Abdurrahaman Wahid, “Asal Usul Tradisi Keilmuan Pesantren,” Jurnal Pesantren, Oktober 1984, 39.

${ }^{2}$ Hadi Mulyo, Pesantren dan Perubahan Sosial. (Jakarta: Pustaka Hidayah, 1985), 99. 
pendidikan yang ditekuninya, pesantren mampu memberikan pencerahan kepada masyarakat Indonesia.

Keberadaan pesantren sebagai lembaga pendidikan sangat melekat dalam perjalanan sejarah kehidupan bangsa Indonesia. Jauh sebelum NKRI terbentuk, pesantren telah berkontribusi dalam mencerdaskan masyarakat Nusantara. Bahkan, jejak karyanya masih bisa dinikmati oleh masyarakat Indonesia sampai saat ini. Kendati demikian, para ahli berbeda pendapat tentang kapan pesantren berdiri pertama kali di Indonesia. Ronald Alan LukensBull menyatakan bahwa Syeikh Maulana Malik Ibrahin merupakan perintis pertama pendidikan pesantren yaitu pada tahun 1399 M. ${ }^{3}$ Sementara itu, Steenbrink menyebutkan bahwa pesantren tertua di Indonesia adalah pesantren Tegalsari Ponorogo yang didirikan sekita akhir abad ke-18 M. ${ }^{4}$

Keberadaan pesantren di Tanah Air terus berkembang baik secara kuantitas maupun kualitas. Pesantren dianggap sebagai model kreasi pendidikan yang berkrakter budaya Indonesia sehingga sangat cocok dengan kehidupan masyarakat Indonesia. Oleh karena itu, Ki Hajar Dewantoro dan Dr. Soetomo pernah berkeinginan untuk menjadikan model pendidikan pesantren sebagai model pendidikan nasional. Nurcholish Madjid menyatakan pendidikan nasional Indonesia akan bermodel seperti pesantren andaikan tidak ada penjajah, di dunia Barat-pun, perguruan tinggi yang eksis dan terkenal sampai saat ini bermula dari lembaga pendidikan yang berorientasi keagamaan seperti Universitas Harvard. ${ }^{5}$

Pesantren diharapkan menjadi mitra bagi pemerintah untuk menyiapkan sumber daya manusia yang memiliki kecerdasan emosional, intelektual, sosial, dan spiritual. Apalagi keberadaan pesantren sudah tidak disangsikan lagi karena pemerintah sudah menerbitkan UU No 18 tahun 2019 tentang Pesantren. Namun demikian pesantren harus terus berbenah diri baik dalam aspek sumber daya manusia, sarana prasarana, maupun manajemen serta proses pembelajarannya sehingga keberadaannya terus dibutuhkan oleh masyarakat serta mampu mencetak kader-kader bangsa yang mumpuni. Karena itu, orientasi pesantren tidak hanya menjadi

${ }^{3}$ Ronald Alan Lukens-Bull, A Peaceful Jihad: Javanese Education and Religion Identity Construction, (Michigan: Arizona State University, 1977), 6o.

${ }^{4}$ Karel A. Steenbrink, Pesantren Madrasah Sekolah, Pendidika Islam dalam Kurun Modern, (Jakarta: LP3ES, 1994), 42.

${ }^{5}$ Nurcholish Madjid, Bilik bilik Pesantren, (Jakarta: Paramadida, 1997), 3. 
lembaga yang tafaqqahu fi al-din, namun harus mampu menjadi lembaga pendidikan yang menghasilkan out put maupun out come yang mempuni sesuai dengan perkembangan ilmu pengetahuan dan tekhnologi.

Keberadaan lembaga pendidikan dengan model boarding school merupakan alternatif yang diharapkan oleh masyatakat, kondisi ini menjadi peluang bagi pesantren yang dari awal sudah menerapkan pendidikan model boarding school, namun demikian pesantren harus melakukan terobosan untuk meningkatkan lembaga pendidikannya dengan cara berbenah diri mulai dari aspek menejerial, aspek kepemimpinan, aspek sarana dan prasarana, aspek jaringan dan lain sebaginya. Sebab tanpa berbenah dengan baik maka peluang yang dimiliki oleh pesantren bisa di ambil oleh lembaga-lembaga lainnya. Namun demikian, pesantren tidak boleh tercerabut dari akarnya yaitu sebagai lembaga pendidikan yang berorientasi pada perbaikan moral atau akhlaq santri.

Penelitian ini menggunkan pendekatan deskriptif. Adapun data diambil dari berbagai sumber seperti jurnal ilmiah, buku referensi, berita surat kabar maupun berita elektronik melalui internet, dan diperkuat dengan diskusi dengan para praktisi pesantren.

\section{Pembahasan}

\section{Dinamika perkembangan pesantren: sebuah telaah historis}

Pesantren merupakan lembaga pendidikan yang berorientasi kegamaan dan menyatu dengan masyarakatnya. Bahkan tidak jarang berdirinya pesantren diinisiasi oleh masyarakat, sehingga pesantren hidup dari masyarakat dan keberadannya untuk masyarakat. Karena itu pesantren dituntut untuk berperan dan berfungsi sejalan dengan kondisi masyaraatnya yang terus berkembang.

Pesantren dipahami sebagai lembaga tafaqquh fi al-din, namun dalam perkembangannya pesantren tidak hanya berorintasi pendidikan keagamaan tetapi dituntut juga untuk berupaya membentuk individu yang unggul diberbagai bidang, membentuk pemahaman agama dan keberagaman yang moderat, meningkatkan kualitas hidup masyarakat (UU 18/2019 pasal 3). Karena itu pesantren berusaha mendidik para santri agar memiliki wawasan keislaman yang luas, keterampilan untuk menunjang kebutuhan hidupnya serta kemampuan untuk mentranspormasi ilmu dan 
prilaku bagi masyarakatnya setelah menyelesaikan pendidikannya di pesantren.

Eksistensi pesantren yang tetap bertahan bahkan terus berkembangn sampai saat ini sangat menarik untuk ditelaah, karena selama ini banyak pihak yang meragukan kemapuan pesantren untuk bertahan ditengan perkembangan dunia global yang ditandai oleh tuntutan masyarakat yang semakin beragam dan semakin kompetitif. Bahkan, pesantren dipredeksi tidak mampu bersaing dengan pendidikan-pendidikan umum dan modern seperti yang diterapkan dinegara-negara barat, karena pesantren diasumsikan sebagai lembaga pendidikan yang terbelakang kumuh dan ketinggalan zaman. Bahkan santri yang menuntut ilmu di pesantren dipersonifikasikan sebagai orang yang jumud, kumuh penyakitan, miskin dan lain sebaginya. Persepsi negatif ini diakibatkan oleh adanya pemahaman dan pengetahuan tentang pesantren yang sangat terbatas, mereka melihat pesantren sebagai lembaga pendidikan tua yang memiliki berbagai macam kelemahan, tanpa mengenal watak pesantren yang terus berbenah dan berkembang bahkan melampui apa yang mereka perkirakan, karena dipesantren tidak hanya diajarkan ilmu pengetahuan keagamaan tetapi juga ilmu pengetahuan umum serta keterampilan-keterampilan yang di butuhkan oleh santri.

Pesimisme terhadap eksistensi pesantren yang memprediksi pesantren akan kehilangan relevansinya dalam kehidupan sosial masyarakat Indonesia sudah mulai terjawab misalnya pada elemen pokok berdirinya pesantren yang hanya terdiri dari asrama, rumah pengasuh, masjid atau musolla, santri, pengajian kitab kuning. Sebagaimana dinyatakan oleh Greertz, Bruinessen, ${ }^{6}$ Dhofier dan Zeimek, dan beberapa ilmuwan lainnya, pesantren saat ini sudah mengalami perkembangan yang sanagt pesat, karena di pesantren sudah terdapat gedung perguruan tinggi, pusan keterampilan, laboratorium, perpustakaan, pusat oleh raga, balai pengobatan, koperasi bahkan ada beberapa pesanyten yang sudah memiliki jaringan TV multimedia, dan ada pesantren yang memiliki penerbitan buku dan lain sebaginya. ${ }^{7}$

Tidak hanya sarananya yang sudah berkembang secara pesat, kurikulum pendidikannya pun tidak hanya fokus pada pembela-

\footnotetext{
${ }^{6}$ Martin van Bruinessen, Kitab Kuning, Pesantren dan Tarekat, (Bandung: Mizan, 1995)

${ }^{7}$ Kontowijoyo, Paradigma Islam: Interpretasi untuk Aksi, (Bandung: Mizan, 1991), 81.
} 
jaran keagamaan khususnya kitab-kitab kuning, tetapi juga terdapat pelajaran umum dan keterampilan, sehingga di pesantren tidak dikenal dikotomi antara pelajaran agama dan pelajaran umum. Banyak pesantren yang mendirikan sekolah-sekolah umum mulai dari jenjang SD, SMP dan SMA-SMK bahkan Perguruan Tinggi seperti Pesantren Genggong, Pesantren Nurul Jadid dan lain sebaginya. Sistem Pengajarannya tidak hanya mempertahankan model salaf seperti sorogan, wetonan, tetapi sudah mengadopsi sitem madrasah. Pada aspek manajemen, pesantren juga mengalami perubahan dari yang bermodel kepemimpinan yang tersentral pada pengasuh, menjadi model kepemimpinan yang kolektif karena sudah banyak berdiri yayasan-yayasan di pondok pesantren.

\section{Manajemen dan Pengembangan Pesantren; sebagai alternatif kontinyuitas di era global}

Pengertian Manajemen

Ada beberapa pengertian tentang manajemen di ataranya manjemen diartikan sebagai pencapaian tujuan-tujuan organisasi secara efektif dan efisien melalui perencanaan, pengelolaan, kepemimpinan dan pengendalian sumberdaya-sumber dana organisasi. ${ }^{8}$ Sementara itu, George R. Terry mengatakan manajemen adalah suatu proses atau kerangka kerja yang melibatkan bimbingan atau pengarahan suatu kelompok orang-orang kearah tujuan-tujuan organisasi atau maksud-maksud yang nyata. ${ }^{9}$ Lebih lanjut, Manullang mengatakan manajemen adalah Seni dan ilmu perencanaan, pengorganisasian, pengarahan, dan pengawasan daripada sumber daya manusia untuk mencapai tujuan yang telah ditentukan terlebih dahulu. ${ }^{10}$ Jadi Manajemen adalah suatu cara untuk mencapai tujuan organisasi secara efektif dan efesian.

Oleh karena itu manajmen menjadi sesuatu yang sangat penting bagi sebuah organisasi termasuk di dalamnya lembaga pendidikan dan pesantren. Tanpa manajemen, lembaga tersebut akan kesulitan untuk mencapai tujuan yang sudah direncanakan. Bahkan lembaga pendidikan yang sangat sederhana seperti Taman Pendidikan Alquran (TPQ) juga membutuhkan sentuan manajmen

\footnotetext{
${ }^{8}$ Richard L Daft, New Era of Management, $9^{\text {th }}$ Ed., Alih Bahasa Tita Maria Kanita, (Yogjakarta: Salemba, 2010), 6.

${ }^{9}$ George R. Terry, Principles of Management, Alih Bahasa GA Ticoalu, (Jakarta: Sinar Grafika Offset, 1992), 1.

10 M. Manullang, Manajemen Personalia, Edisi Revisi, (Jakarta: Ghalia Indonesia, 1981), 11.
} 
agar targen pendidikannya tercapai secara maksimal serta proses pembelajarannya bisa berlangsung secra efektif dan efesien.

\section{Pengartian Pesantren}

Pesantren yang awalnya sebagai lembaga pendidikan Islam tradisional ${ }^{11}$ memiliki secara panjang di Nusantara. sejarah ini mempengaruhi pengertian tentang pesantren itu sendiri. Ada beberapa pengertian pesantren di antaranya "Pesantren adalah institusi lokal yang mengajarkan praktik-praktik dan kepercayaankepercayaan Islam." ${ }^{\prime 2}$ Pesantren merupakan lembaga keagamaan yang mendidik santrinya agar senantiasa berpegang teguh pada Alquran dan Hadits Nabi Muhammad sehingga menjadi insan yang mempunyai komitmen dan konsistensi dalam setiap waktu dan kondisi. ${ }^{13}$

Secara lahiriyah pesantren merupakan komplek yang lokasinya terpisah dari masyarakat sekitar, dan terdapat beberapa bangunan yang memiliki fungsi berbeda seperti bangunan musollah atau masjid, asrama untuk tempat tinggal santri dan bangunan sebagai tempat tinggal Kiai. ${ }^{14}$ Namun demikian, Karel A. Steenbrink yang mengutip dari Soegarda Purbakawatja, menyatakan bahwa pesantren bukan lembaga pendidikan asli Indonesia, karena dari segi bentuk dan sistemnya berasal dari India dan dari masyarakat Hindu. ${ }^{15}$ Sebelum Islam datang ke Indonesia sistem pembelajaran seperti pesantren sudah ada, biasanya digunakan untuk pengajaran agama Hindu. Namun, ketika Islam berada di Jawa, sistem pengajaran tersebut diadopsinya. Berbeda dengan Steenbrink, menurut Mahmud Yunus, pendidikan model pesantren sudah ada di Bagdad dan menjadi model pendidkan di sana.

\section{Sistem Manajemen Pesantren}

Sebelum membahas sistem manajemen pesantren maka harus dipahami terlebih dahulu apa itu sistem. Sistem merupakan satu kesatuan yang terdiri dari berbagai komponen yang saling terkait, saling berhubungan untuk mencapai suatu tujuan dengan

${ }^{11}$ Sulthan Fatoni, Peradaban Islam; Desain Awal Peradaban, Konsolidasi Teologi, Konstruk Pemikiran dan Pencarian Madrasah, eLSAS, Jakarta, 2006), 164165.

${ }^{12}$ Ronal Alan Lukens-Bull, A Peaceful Jihad, 165.

${ }^{13}$ Sulthan Fatoni, Peradaban Islam, 134.

${ }^{14}$ Abdurrahman Wahid, Islam Kosmopolitan: Nilai-Nilai Indonesia dan Transformasi Kebudayaan, (Jakarta: The Wahid Institute, 2007).

${ }^{15}$ Karel A. Steenbrink, Pesantren Madrasah Sekolah, 22. 
cara efektif dan efesien. Keberadaan pondok pesantren tidak bisa terlepas dari sosok figur kiai, karena kiai sebagai tokoh sentral, pengambil kebijakan bahkan corak pesantren sangat bergantung kepada kiai, dominasi kepemimpinan kiai di pesantren dipengaruhi oleh dua hal.

Pertama, model kepemimpinan di pesantren yang bersifat sentralistik yang pertumpu pada kharisma kiai, sehingga hubungan yang terjadi bersifat bersifat paternalistik. Kondisi ini berpengaruh pada pola manajemen yang dianutnya. Karena itu banyak pesantren yang menggunakan pola menejemen tunggal, sehingga tidak ada pembagian wewenang kepada masing-masing unit kerja.

Kedua, pesantren didirikan atas inisiasi kiai dan seluruh kebutuhannya bersumber dari dana milik kiai dan keluarga, sehingga kepemilikan pesantren bersifat individu atau keluarga, bukan milik umum. Keberadaan kiai sebagai pendiri, pengasuh dan memilik pesantren sangat berpengaruh pada pola manajemen yang dianutnya. Bahkan, dalam persolaan peralihan kepemimpinan, faktor keturunan menjadi penentunya, seorang kiai bisa mewariskan kepemimpinan pesantren kepada anaknya atau keluarganya. ${ }^{16}$

Namun seiring dengan keberadaan pesantren yang mengadopsi model pendidikan formal, mulai dari jenjang pendidikan dasar, menengah bahkan pendidikan tinggi, beberapa pesantren mengalami perkembangan baik dari aspek pengorganisasian, pengelolaan keuangan, pengelolaan sumber daya manusia dan lain sebaginya. Perkembangan ini berpengaruh pada pola kepemimpinan pesantren yang awalnya bertumpu pada kiai dan bersifat sentralistik, mulai bergeser kepada model kepemimpinan yang rasional dan parsisipatif, seperti yang terjadi di Pesantren Tebuireng Jombang, dalam pengelolaan pesantren dibentuklah dewan kiai, yang memiliki kewenangan mengelola pesantren, sehingga kekuasan tidak terpusat pada pengasuh tetapi sudah terdistribusi kebeberapa elit pesantren. ${ }^{17}$ Bahkan, di beberapa pesantren sudah terbentuk kepengurusan yang mengelola unit-unit kegiatan dipesantren mulai dari pendidikan formal, pendidikan diniyah, urusan rumah tangga kepesantrenan, saran prasarana pesantren dan lain sebaginya, pola kerja antara unit sudah berjalan

\footnotetext{
${ }^{16}$ Sulthon Masyhud, dkk., Manajemen Pondok Pesantren, (Jakarta: Diva Pustaka, 2003), 14-15.

${ }^{17}$ Amin Haedari dan Ishom El-Saha, Peningkatan Mutu Terpadu Pesantren dan Madrasah Diniyah, (Jakarta: Diva Pustaka, 2008), 9.
} 
dengan baik, walaupun demikian kiai sebagai pengasuh tetap memilki pengaruh yang signifikan. ${ }^{18}$

Perkembangan yang terjadi dibeberapa pesantren masih belum bisa diikuti oleh pesantren-pesantren yang lainnya, karena secara umum pesantren masih menghadapi berbagai problem dalam mengembangakan pendidikannya seperti penerapan manajemen yang masih sangat konvensional sehingga tidak ada distribusi yang jelas antara kewenangan pengasuh, kepala sekolah guru dan staf administrasi, pengelolaan keuangan yang belum transparan, masih belum bakunya system administarsi yang dilaksanakan. Di samping itu pesantren masih memiliki keterbatasan sumberdaya manusia yang profesional sehingga belum bisa mengelola pendidikannya sesuai dengan standar yang telah ditetapkan oleh pemerintah. Dan banyak problem yang masih dihadapi oleh pesantren sehingga pengembangan pesantren terkesan lambat dan tidak terencana dengan baik karena banyak pesantren yang belum memiliki rencana induk pengembangan pesantren sebagai pedoman dalam mengelola pendididkan yang dimilikinya. ${ }^{19}$

Kondisi pesantren sering menyebabkan adanya ketimpangan antara teori pengembangan lembaga pendidikan dengan realitas yang terjadi di pesantren. Satu sisi, berpegang pada teori yang normatif dengan mengabaikan kondisi obyektif yang ada di pesantren merupakan tindakan yang kurang bijaksana. Di lain pihak, membiarkan pesantren berkembangan tidak sesuai dengan standar yang ada juga merupakan tindakan yang kurang arif. Oleh karena itu, harus ada ikhtiar untuk selalu mengembangkan pesantren dalam rangka menuju pesantren yang ideal namun tetap memperhatikan potensi kondisi riil pesantren sehingga tidak menimbulkan konflik yang justru merugikan semua pihak.

\section{Kombinasi Idealisme dan Profesionalisme Pesantren}

Sebagai lembaga pendidikan keagamaan, pondok pesantren dalam aktivitasnya senantiasa di dasari oleh keinginan untuk mendapatkan ridha dari Allah sehingga oreintasinya tidak hanya ingin mendapatkan keuntungan duniawiyah tetapi juga menginginkan kebahagian akhirat, karena itu dipesantren selalu ditanamkan jiwa ketulusan, keiklasan, kesukarelaan. Konsep lillahi ta'ala ini merupakan kelebihan yang dimiliki oleh pesantren sehingga

18 Zamaksyari Dhofier, Tradisi Pesantren: Studi Tentang Pandangan Hidup Kiai, (Jakarta: LP3ES, 1982), 80.

${ }^{19}$ Sulthon Masyhud, dkk., Manajemen Pondok Pesantren, 16. 
aktivitasnya dilandasi pengabdian yang sangat luar biasa. Namun demikian, konsep tersebut harus disertai dengan kemampuan dan keahlian yang memadahi sehingga para pengelola pesantren bisa bekerja secara profisional. Kalau kedua modal ini bisa dimiliki oleh pengelola pesantren pasti akan melahirkan sumber daya yang sangat ideal karena mampu mengkombinasikan antara idealisme yang bertumpu kepada nilai-nilai tauhid dengan sikap profesionalisme yang didasari oleh kemapuan mengelola lembaga sesuai dengan standar-standar modern. Kombinasi manajemen ideal tersebut diharapkan mampu mempertahankan eksistensi pesantren bahkan mampu bersaing dengan lembaga-lembaga modern lainnya. Bahkan, pesantren mampu melahirkan konsep manajemen yang berbasis pesantren. Manajmen ini memilik karakter yang bisa dianalisa melalui pendekatan sistem, yaitu dari segi input-prosesoutput. Manajmen ini diharapkan mampu menunjang dinamika pondok pesantren secara keseluruhan. ${ }^{20}$ Untuk lebih jelasnya kami uraikan sebagai berikut:

1. Output yang diharapkan.

Lulusan pesantren diharapkan memiliki prestasi yang tidak kalah dibandingkan dengan lembaga pendidikan lainnya mereka harus memiliki prestasi akademik bidang keagamaan maupun umum, memiliki kecakapan dan keterampilan dan perestasi lainnya yang bersifat non akademik.

2. Proses

Pelaksanaan pembelajaran di Pesantren harus mengacu kepada outpun yang ditargetkan, sehingga seluruh sumber daya yang ada digerakkan menuju satu tujuan yaitu santri yang unggul dibidang akademik, non akademik dan memiliki keterampiran serta kecakapan hidup.

3. Input podok pesantren

Input pesantren harus sesuai dengan karakter dan kondisi kondisi yang ada di pesantren sehingga input ini bisa dip roses sesuai dengan target output yang telah ditetapkan.

\section{Pengembangan Pesantren}

${ }^{20}$ MU YAPPI, Manajemen Pengembangan Pondok Pesantren, (Jakarta, Media Nusantara, 2008), 19. 
Abad ke-2o yang ditandai dengan kemajuan ilmu pengetahuan dan teknologi menjadi tantangan tersendiri bagi pesantren, karena pesantren di tuntut untuk mampu berdaptasi dengan perkembangan jaman, sehingga bisa memberikan kontribusi yang cukup signifikan, karena semenjak Belanda memperkenalkan pendidikan modern dengan model sekolah, peran pesantren mengalami pergeseran yang cukup signifikan. ${ }^{21}$ Apalagi, pemerintah Indonesia sejak merdeka telah mengadopsi pendidian sistem barat dengan model sekolah seperti yang dilakukan oleh penjajah Belanda. Sementara itu, pesantren dan pendidikan keagamaan masih belum mendapatkan tempat yang terhormat dalam sistem pendidikan di Indonesia. Baru pada tahun 2019 ketika ditetapkannya UU No 18 tahun 2019 tentang Pesantren, keberadaan pesantren diakui sebagai bagian dari system pendidikan nasional.

Pelaksanaan pendidikan di pesantren yang disudah berlangsung cukup lama dan tersebar hampir diseluruh penjuru tanah air ternyata belum memiliki kurikulum yang bersifat standar, sehingga setiap pesantren mempunyai kemandirian untuk menentukan kurikulumnya sesuai dengan latar belakang didirikannya pesantren tersebut, sehingga model pendidikan di pesantren sangat beragam seperti adanya pesantren salaf yang kurikulumnya hanya memuat materi-materi keagamaan tanpa adanya materi pendidikan umum. Ada juga pesantren modern yang kurikulumnya telah mengombinasikan antara pendidikan keagamaan dan pendidikan umum. Pesantren model ini biasanya disebut dengan pesantren modern. Di samping itu, pesantren secara umum belum terorganisasi menjadi satu jaringan, namun setiap pesantren bisa berdiri sendiri atau masuk pada jaringan-jaringan yang lebih bersifat ideologis misalnya Nahdlatul Ulama punya jaringan pesantren yang diwadahi oleh Robithoh Ma'ahid Islamiyah (RMI). Namun demikian, keberadaan RMI sebatas koordinasi tidak bersifat komando karena setiap pesantren yang berada dalam jaringan RMI bersifat independen.

Pendidikan di pesantren mengalami perkembangan yang cukup signifikan pada masa sejak Orde Baru sampai saat ini. Hal ini ditandai dengan banyaknya pesantren yang sudah memiliki kurikulum baku serta pengelolaan dengan pendekatan manajemen modern. Bahkan tidak jarang pesantren sudah menerapkan kurikulm yang integral antara pendidikan keagamaan dan pendidikan umum dengan presentase 70 porsen pendidikan umum

\footnotetext{
${ }^{21}$ Aqib Suminto, Politik Islam Hindia Belanda, (Jakarta: LP3ES, 1985), 76.
} 
dan 30 porsen pendidikn agama seperti yang diterapkan oleh madrasah-madrasah. ${ }^{22}$ Pesantren tidak pernah berhenti melakukan pengembangan baik yang menyangkut kurikulum, pengelolaan, dan penyediaan sumber daya manusia. Hal ini semata-mata dilakukan hanya untuk berkontribusi dalam pengembangan masyarakat Indonesia. Namun perkembangan pesantren berjalan secara simultan walaupun terkesan lambat. Said Agil Siraj menyatakan ada tiga hal yang perlu dikuatkan oleh pesantren. Pertama, tamaddun yaitu memajukan pesantren. Pesantren yang selama ini dikelola secara alamiah dan sederhana dan bertumpu pada kiai harus melakukan pembenahan dengan mengadopsi pengelolaan lembaga pendidikan yang baik. Kedua, tsaqafah, yaitu memberikan pencerahan kepada umat Islam khususnya santri sehingga mereka bisa kreatif dan produktif, misalnya santri tidak hanya menguasai kitap kuning tetapi juga mampu beradaptasi dengan ilmu pengetahuan serta sains modern. Ketiga, hadharah, yaitu membangun budaya, bagaimana pesantren bisa membangun budaya Islami ditengan terpaan arus globalisasi. ${ }^{23}$

Pesantren dalam mengembangkan dirinya sebagai lembaga pendidikan keagamaan mengalami beberapa kendala di antaranya:

1. Image masyarakat yang mengagap pesantren sebagai tempat pendidikan yang kumuh, tradisional, ketinggalan zaman, bahkan dianggap melahirkan orang islam yang radikal, image ini disatu sisi menjadi beban bagi pesantren namundi sisi lain menjadi tantangan yang harus dijawab oleh pengelola pesantren.

2. Sarana dan prasarana yang masih bersifat sederhana, untuk mengembangan pesantren menjadi lembaga pendidikan yang modern membutuhkan biaya yang cukup banyak khususnya dalam penyediaan sarana dan prasaran. Kondisi ini yang kemudian menyebabkan pesantren tidak bisa berkembnag secara optimal, karena pembiyaan pesantren biasanya masih bergantung pada pengasuh. Pesantren belum belum memiliki sumber dana yang mengucur secara terus-menerus. Karena itu sering terlihat sarana prasarana yang ada dipesantren sangat memprihatinkan.

3. Sumber daya manusia. Di pesantren SDM yang ada biasanya banyak berlatar belakan pendidikan keagmaan,

${ }^{22}$ Sulthon Masyhud, dkk., Manajemen Pondok Pesantren, 73.

${ }^{23}$ Sulthon Masyhud, dkk., Manajemen Pondok Pesantren, 73. 
sementara SDM yang memiliki keahlian non keagamaan sanagt sedikit, hal ini sangat berpengaruh bagi pengembangan pesantren.

4. Aksesibilitas dan networking. SDM pesantren yang monoton pada kemampuan bidang keagamaan, menyebabkan pesantren kurang mampu membangun akses dan jaringan untuk pengembangan pesantren, hanya pesantren tertentu saja yang memiliki akses dan jaringan yang sudah mapan.

5. Manajemen kelembagaan. Dalam pengelolaan lembaga, banyak pesantren yang masih menggunakan pendekanan manajemnen tradisional dan biasanya sangat bergantung kepada pengasuh, karena itu sudah waktunya pesantren dalam mengelola pendidikannya dengan menggunakan menajemen modern sehinga seluruh proses pendidikannya bisa terstandar.

6. Pembenahan administrasi. Administarasi pesantren biasanya masih dikelola secara tradisional sehingga banyak dokumen penting yang tidak ada, sepert buku induk siswa, struktur pengurus dan lain sebaginya.

7. Kemandirian ekonomi kelembagaan. Dalam pengembangan pendidikannya, pesantren membutuhkan modal yang sangat pesar, karena itu pesantren harus berupaya untuk menciptakan kemandirian secara ekonomi dengan mengelola seluruh potensi yang dimilikinya dengan baik.

8. Kurikulum yang berorientasi life skills santri dan masyarakat. Santri dipesantren tidak hanya dibekali kemampuan bidang keagamaan, tetapi perlu juga di bekalai keterampilan yang bisa menopang kehidupannya setelah keluar dari pesantren. ${ }^{24}$

\section{Karakter dan Kecenderungan di Pesantren: Wujud Budaya Akhlak}

Pesantren memiliki kemampuan untuk senantiasa beradaptasi dengan perkembangan yang terjadi di masyarakat sehingga pesantren tetap eksis sampai saat ini. Kemampuan readjustment terhadap perubahan yang terjadi merupakan kekuatan yang dimiliki oleh pesantren, sehingga pesantren dengan mudah melakukan perubahan sesuai dengan tuntutan masyarakat

${ }^{24}$ Sulthon Masyhud, dkk., Manajemen Pondok Pesantren, 23. 
dan perkembangan zaman, kemampuan beradaptasi menjadi karakter khas yang dimiliki pesantren.

Pesantren memiliki karakter dan kecenderungan yang berkembangan secara dinamis sehingga pesantren tetap eksis bahkan memiliki potensi untuk menjadi pendidikan alternatif ideal untuk memenuhi kebutuhan masyarakat modern, ditengan system pendidikan modern yang hanya mementingkan sisi lahiriyah manusia. Karakter dan kecenderungan tersebut antara lain:

1. Pesantren memiliki hubungan emosional dengan masyarakatnya sehingga lembaga ini mengakar dan menyatu dengan masyarakatnya, sehingga pesantren memiliki lingkungan, dan lingkungan memiliki pesantren jadi hubungan kedunya bagaikan dua sisi mata uang yang tidak bisa di pisah.

2. Pesantren memiliki prinsip Panca Jiwa, lima jiwa yang menjadi kekuatan pesantren diantaranya keikhlasan, kesederhanaan, kemandirian, ukuwah Islamiyah dan kebebasan. Abd. Halim Soebahar menyatakan hakikat pendidikan di pesantren adalah membina panca jiwa ini, karena ini sangat menentukan falsafah hidup santri setika sudah menyelesaikan pendidikannya di pesantren, sehingga santri bukan hanya siap pakai tetapi santri siap hidup. ${ }^{25}$

3. Hubungan santi dan kiai yang akrab karena kiai bukan hanya guru ta'lim, tetapi juga sebagai guru ta'dzib dan guru tarbiyah. Kiai tidak hanya mendidik santri paham ilmu-ilmu keislaman tetapi yang lebih penting dari itu adalah upaya kiai untuk menjadikan santri taqurrub ilallah

4. Santri harus berada di Asrama. Pengasramaan santri memiliki keungulan dalam pelaksanaan pendidikan, karena santri bisa hidup lebih elegan tanpa melihat latar belakang teman santri yang lainnya, yang kaya dan yang miskin memiliki posisis yang sama. Di samping itu, dengan model pengasramaan, kiai bisa mengkontrol kehidupan santri baik dalam aspek pengetahuan maupun aspek prilaku, kiai juga memberikan pendampingan untuk melatih santri agar setelah menyelesaikan pendidikannya mampu beradaptasi dengan masyarakatnya.

5. Fleksibel terhadap berbagai perubahan yang terjadi. Pesantren memiliki slogan "Al-muhafadatu ala al-qadim alsaleh wa al-ahdu bi al-jadidi al-ashlah" (memelihara sesuatu

${ }^{25}$ Abd. Halim Soebahar, "Pesantren Gender" (Laporan Penelitian DIPA STAIN Jember, 2002). 
yang lama dan baik, tetapi juga mengambil sesuatu yang baru yang lebih baik). Slogan inilah yang menyebankan pesantren tetap eksis bahkan terus berkembang sampai saat ini $^{26}$ dan perkembangan pesantren tidak menutup kemungkinan menjadikannya sebagai lembaga pendidikan alternatif yang ideal untuk masa depan.

\section{Simpulan}

Pesantren sebagai lembaga pendidikan memiliki peluang yang sangat besar untuk menjadi lembaga pendidikan alternatif ideal bagi masa depan, karena pesantren mampu mengombinasikan antara kecerdasan intelektual dan kecerdasan spiritual serta kecerdasan sosial. Modal ini harus selalu dipertahankan oleh pesantren. Pesantren tidak boleh menjadi lembaga yang jumud, lembaga yang alergi dengan perubahan. Pesantren harus menjadi lembaga pendidikan yang integralistik, humanistik, pragmatik, idealistik dan realistik, sehingga model pendidikan yang diidealkan oleh masyarakat, sebuah model yang mampu memberikan keseimbangan antara iman, ilmu dan amal shaleh. Pesantren juga harus ditopang oleh manajemen yang professional dan kepemimpinan yang efektif dan efesian sehingga menghasilkan output yang tidak hanya sukses sebagai mahluk individu tetapi juga mampu merealisasikan dirinya sebagai mahluk sosial. Perubahanperubahan yang harus dilakukan oleh pesantren diyakini oleh penulis bisa di realisasikan karena pesantren memiliki prinsip Almuhafadatu ala al-qadim al-saleh wa al-ahdu bi al-jadidi al-ashlah. Prinsip ini yang menjadi modal bagi pesantren untuk terus berbenah diri dalam segala aspek baik aspek manajemen, pengembangan SDM, aspek kepemimpinan, aspek sarana dan prasarana dan aspek-aspek yang lainnya. Harapannya, pesantren memainkan peran yang signifikan dama bidang pendidikan untuk menyiapkan SDM Indonesia yang handal, berkarakter dan memiliki kualitas yang memadahi serta mampu mengintegralkan keuatan iman, kemampuan ilmu pengatahuan serta mengaplikasikan dalam bentuk amal sholeh.

\section{DAFTAR PUSTAKA}

Bruinessen, Martin Van, Kitab Kuning, Pesantren dan Tarekat, Bandung: Mizan, 1995.

\footnotetext{
${ }^{26}$ Hadi Mulyo, Pesantren dan Perubahan Sosial, 99.
} 
Bull, Ronald Alan Lukens, A Peaceful Jihad: Javanes Education and Religion Identity Construction, Michigan: Arizona State University, 1977.

Daft, Richard L. New Era of Management, $9^{\text {th }}$ Ed. Alih Bahasa Tita Maria Kanita, Yogyakarta: Salemba, 2010.

Dhofier, Zamaksyari, Tradisi Pesantren: Studi Tentang Pandangan Hidup Kiai, Jakarta: LP3ES, 1982.

Fatoni, Sulthan, Peradaban Islam: Desain Awal Peradaban, Konsolidasi Teologi, Konstruk Pemikiran dan Pencarian Madrasah, Jakarta: elSAS, 2006.

Haedari, Amin dan Ishom El-Saha, Peningkatan Mutu Terpadu Pesantren dan Madrasah Diniyah, Jakarta: Departemen Agama, 2008.

Kontowijoyo, Paradigma Islam: Interpretasi untuk Aksi, Jakarta: Mizan, 1991.

Madjid, Nurcholish, Bilik Bilik Pesantren, Jakarta: Paramadida, 1997.

Manullang, M., Manajemen Personalia, Edisi revisi, Jakarta:Ghalia Indonesia, 1981.

Masyhud, Sulthon, dkk. Manajemen Pondok Pesantren, Jakarta: Diva Pustaka, 2003.

MU YAPPI, Manajemen Pengembangan Pondok Pesantren, Jakarta: Media Nusantara, 2008.

Mulyo, Hadi, Pesantren dan Perubahan Sosial. Jakarta: Pustaka Hidayah, 1985.

Soebahar, Abd. Halim, Pesantren Gender. Laporan Penelitian DIPA STAIN Jember, 2002.

Steenbrink, Karel A., Pesantren Madrasah Sekolah: Pendidikan Islam dalam Kurun Modern, Jakarta: LP3ES, 1994.

Suminto, Aqib, Politik Islam Hindia Belanda, Jakarta: LP3ES, 1985.

Terry, George R. Principles of Management, Alih Bahasa GA Ticoalu, Jakarta: Sinar Grafika Offset, 1992.

Wahid, Abdurrahaman, "Asal Usul Tradisi Keilmuan Pesantren Jurnal Pesantren Oktober, 1984.

Wahid, Abdurrahman, Islam Kosmopolitan: Nilai-Nilai Indonesia dan Transformasi Kebudayaan. Jakarta: The Wahid Institute Seeding Plural and Peaceful Islam, 2007. 